\title{
Trace Metal
}

\section{Concentrations in an} Agricultural Watershed: Case Study in the Sumani Watershed, West Sumatera Indonesia

\section{Aflizar1, Cornelius Alarima Idowu', Edi Syafri $^{1}$, M. Azadur Rahman ${ }^{3}$, Yoga Andriana Sandjaja ${ }^{4}$, Husnain ${ }^{5}$}

${ }^{1}$ State Polytechnic Payakumbuh for Agriculture, Indonesia 26271

${ }^{2}$ Faculty of Life and Environmental Science, Shimane University, Nishikawatsu 1060, 690-8504, Japan

${ }^{3}$ Department of Geoscience, Graduate School of Science and Engineering, Shimane University, 1060 Nishikawatsu-Cho, Matsue 690-8504, Japan

${ }^{4}$ Department of Geology, Padjadjaran University, Bandung, Indonesia

${ }^{2}$ Indonesia Soil Research Institute, Bogor 16123

Received: January 2, 2014/ Accepted: April 24, 2015

\section{Abstract}

Selected trace metals investigation of agricultural soil at sawah, vegetable and river sediment in Sumani watershed, West Sumatra, Indonesia were conducted to determine their abundances and to assess contamination levels. $\mathrm{pH}$, CEC and TC values indicates moderate to high soil fertility status. Average concentrations of $\mathrm{Pb}, \mathrm{Zn}, \mathrm{Cu}, \mathrm{TiO}_{2}, \mathrm{Fe}_{2} \mathrm{O}_{3}$ and $\mathrm{P}_{2} \mathrm{O}_{5}$ were greater than those of Bulk Composition Crust (BCC) and UCC in most areas. Enrichment factor values at Sawah confirms depletion to minimal enrichment with most metals, while vegetable area indicates moderate enrichment with $\mathrm{Pb}, \mathrm{Cu}$ and $\mathrm{Rb}$, and depletion to minimal enrichment for $\mathrm{Zn}, \mathrm{Ni}, \mathrm{Cr}, \mathrm{V}$ and $\mathrm{Sr}$. Igeo values for $\mathrm{Pb}$, at Sawah were unpolluted to moderately polluted but practically unpolluted for $\mathrm{Zn}, \mathrm{Cu}$, $\mathrm{Ni}, \mathrm{Cr}, \mathrm{V}$, while vegetable area were moderately polluted with $\mathrm{Pb}$, unpolluted to moderately polluted with $\mathrm{Cu}$ and $\mathrm{Rb}$ and and practically unpolluted for $\mathrm{Zn}, \mathrm{Ni}, \mathrm{Cr}, \mathrm{V}$ and $\mathrm{Sr}$. Elevated values of $\mathrm{Pb}$ in vegetable area, possibly due to volcanic ash from mount Talang, excess application of fertilizers and pesticides, and high contents of $\mathrm{Pb}$ in gasoline, Indonesia.

Keyword: Trace elements; vegetable and sawah soil; environmental evaluation; Sumani watershed.

\footnotetext{
* Corresponding Author
}

Tel.: +62-752-7754192; fax:+62-752-7750220

E-mail:aflizar_melafu@yahoo.comoraflizar@politanipyk.ac.id

Abbreviations:
\begin{tabular}{|llll|}
\hline BCSCST & $:$ & Bulk Composition Sediment & Column \\
& & Subdicting at Trenches \\
BCC & $:$ & Bulk Continental Crust \\
NCJ & $:$ & Non Contaminated Soil in Japan \\
CSJ & $:$ & Contaminated Soil in Japan \\
UCC & $:$ & Upper Continental Crust \\
CF & $:$ & Contamination Factor \\
EF & $:$ & Enrichment Factor \\
Igeo & $:$ & Geo Accumulation Index \\
PLI & $:$ & Pollution Load Index \\
eCEC & $:$ & Effective cation exchange capacity \\
SW & $:$ & Sawah \\
MG & $:$ & Mixed garden \\
Sh & $:$ & Shrub \\
F & $:$ & Forest \\
T & $:$ & Tea \\
St & $:$ & Settlement \\
Vg & $:$ & Vegetable \\
Rs & $:$ & River sediment \\
XRF & $:$ & X-ray fluorescence \\
\hline
\end{tabular}

\section{Introduction}

Soils are complex and heterogeneous mixtures of organic and inorganic matter, as well as the differing components that determine their physical, chemical and biological properties. Soils in agricultural areas (especially gardens) may have a direct influence on public health that is unrelated to production of food, because may come into contact with humans or be transferred to them as suspended dust [1]. Contamination of agricultural soils with heavy metals through repeated use of untreated or poorly treated waste water from industrial establishments, and the application of chemical fertilizers and pesticides is one of the most severe ecological problems in Indonesia [2].

Indonesia is now at the beginning of its third Five-Year Development Plan (TFDP), commonly known as "Repelita III". While the preceding Repelita I and II plans emphasized the development of agriculture, industrialization is now assuming a more important role. Modernization of agriculture and expansion of industry could, unless handled properly, give rise to environmental pollution. Before this occurs, environmental base-line studies should be put in place [3]. Trace elements display a dualistic behavior in their interaction with the Earth's flora and fauna. Many trace elements are essential to the growth and health of both flora (e.g., $\mathrm{Cu}, \mathrm{Zn}, \mathrm{Mn}, \mathrm{Fe}, \mathrm{Mo}$ and $\mathrm{B}$ ) and fauna (e.g., Se, Co - [4]), where they act as catalysts in the processes of life. However, at higher concentrations, these essential nutrients can have a detrimental effect and can become 
toxic to organisms (including humans), via direct exposure, transportation and bioaccumulation in food chains [5].

Trace metals are among the most persistent environmental pollutants in water bodies and biota, but their occurrence in sediments arises from both natural and anthropogenic sources [6]. Trace metals are ubiquitous in aquatic environments [7]. Some of these metal contaminants are crucial due to their potential toxicity [8] and have potential impact on human health if they reach levels such that they constitute toxic pollutants [9].In addition, metals including $\mathrm{Cu}, \mathrm{Fe}, \mathrm{Mn}$, and $\mathrm{Ni}$ are essential micronutrients for the life processes of animals and plants [10], but imbalances of these metals may be fatal [11]. Furthermore, [12] observed that elements such as As, $\mathrm{Pb}$, $\mathrm{Zn}$, and $\mathrm{Cd}$ exhibit extreme toxicity, even at low levels. Elevated concentrations of trace metals in the environment occur as a result of anthropogenic activities such as mining, milling or smelting of ores, application of agricultural fertilizers, and combustion of fuels[13]. Elements can also be enriched by natural processes, such as redistribution and mobilization of trace elements from host rocks or regoliths by surface and subsurface waters, and by flooding events [14].

The role of trace elements in the soil system is becoming an issue of global concern, at both private and governmental levels, since soil constitutes a crucial component of rural and urban environments and constitutes a very important "ecological crossroad" in the landscape [15]. Vegetable crops cultivated in soils polluted with toxic and heavy metals may take up such metals and accumulate them in their edible and non-edible parts in quantities high enough to cause clinical problems in animal and human consumers [16]. Toxicmetals are known to have serious health implications, including carcinogenesis and induced tumor promotion. Growing awareness of the health risks associated with environmental chemicals has also brought a shift in global concern towards prevention of heavy metal accumulation in soils, water and vegetables [17]. Long-term use of industrial or municipal wastewater in irrigation contributions significantly to the content of trace and heavy elements such as $\mathrm{Cd}, \mathrm{Cu}, \mathrm{Zn}, \mathrm{Cr}, \mathrm{Ni}, \mathrm{Pb}$, and $\mathrm{Mn}$ in surface soils [18]. Excessive accumulation of trace elements in agricultural soils through waste water irrigation may thus not only lead to soil contamination, but also affect food quality and safety [19].

The Sumani watershed in West Sumatra, Indonesia, is a prime example of a setting where the use of such water constitutes a potential threat for agricultural ecosystems and human health. Sources of heavy metals in the Sumani watershed include irrigation water, volcanic ash, and residues of fertilizers and pesticides, the use of which has increased since the "green revolution" began in 1972. Vehicle emissions are also a potential source, as gasoline in
Indonesia contains high contents of trace metals, especially $\mathrm{Pb}$. Soil $\mathrm{pH}$, soil physicochemical and geological characteristics could also control availability of heavy metals in agricultural soils in the Sumani watershed. Much of the agricultural area in the Sumani watershed is irrigated with river water that is partly supplied from Lake Dibawah on the west of Mount Talang (2500 m asl), which is an active volcano.

Several environmental studies have been conducted in Indonesia to determine trace metal concentrations, their rates of loading, pollution history, and the extent of contamination from trace metals. These studies have been made in different areas of Sumatra and Java, in both river and coastal sediments $[20,21,16,23]$. However, trace metals in agricultural watersheds with varied land use have received limited attention. Consequently, our present study examines the status of trace metal pollution in the Sumani watershed, to evaluate the influence of anthropogenic activities and impacts on the agricultural soils within it. This study aimed to determine the concentrations and distribution of trace metals $(\mathrm{Pb}, \mathrm{Zn}, \mathrm{Cu}, \mathrm{Ni}, \mathrm{Cr}, \mathrm{V}, \mathrm{Sr}, \mathrm{Rb}, \mathrm{Ce}$, $\mathrm{Th}$ and $\mathrm{Zr})$ and major oxides $\left(\mathrm{Fe}_{2} \mathrm{O}_{3}, \mathrm{CaO}, \mathrm{MnO}, \mathrm{TiO}_{2}\right.$ and $\left.\mathrm{P}_{2} \mathrm{O}_{5}\right)$ in representative soils, to assess the contamination level (if any) in the study area. We employed several procedures including contamination factor (CF), enrichment factor (EF), pollution load index (PLI) and geoaccumulation index (Igeo) to establish the status of selected trace metals. These data also provide the baseline information needed for developing strategies for future pollution control in an agricultural watershed.

\section{Methods}

\subsection{Study area}

The Sumani watershed is located in Solok regency (latitude $0^{\circ} 36^{\prime} 8^{\prime \prime}$ to $1^{\circ} 44^{\prime} \mathrm{o} 8^{\prime \prime} \mathrm{S}$, longitude $100^{\circ} 24^{\prime} 11^{\prime \prime}-101^{\circ} 15^{\prime} 43^{\prime \prime} \mathrm{E}$ ), approximately $50 \mathrm{~km}$ east of Padang City in West Sumatra, Indonesia (Fig. 1). The watershed occupies an area of 58330 ha, and elevation ranges from $300 \mathrm{~m}$ to $2500 \mathrm{~m}$ above sea level (asl). Lake Singkarak is the outlet of the watershed. Average annual precipitation ranges from 1669 to $3230 \mathrm{~mm}$ $[24,25]$ and climate is classed as humid tropical. The Sumani watershed has a variety of land uses, including primary forest, mixed gardens, vegetable gardens, sawah, abandoned agricultural fields, and settlements. The term sawah refers to a levelled and bounded rice field with an inlet and outlet for irrigation and drainage [25]. Lowland areas of the Sumani watershed are both urban and agricultural. 


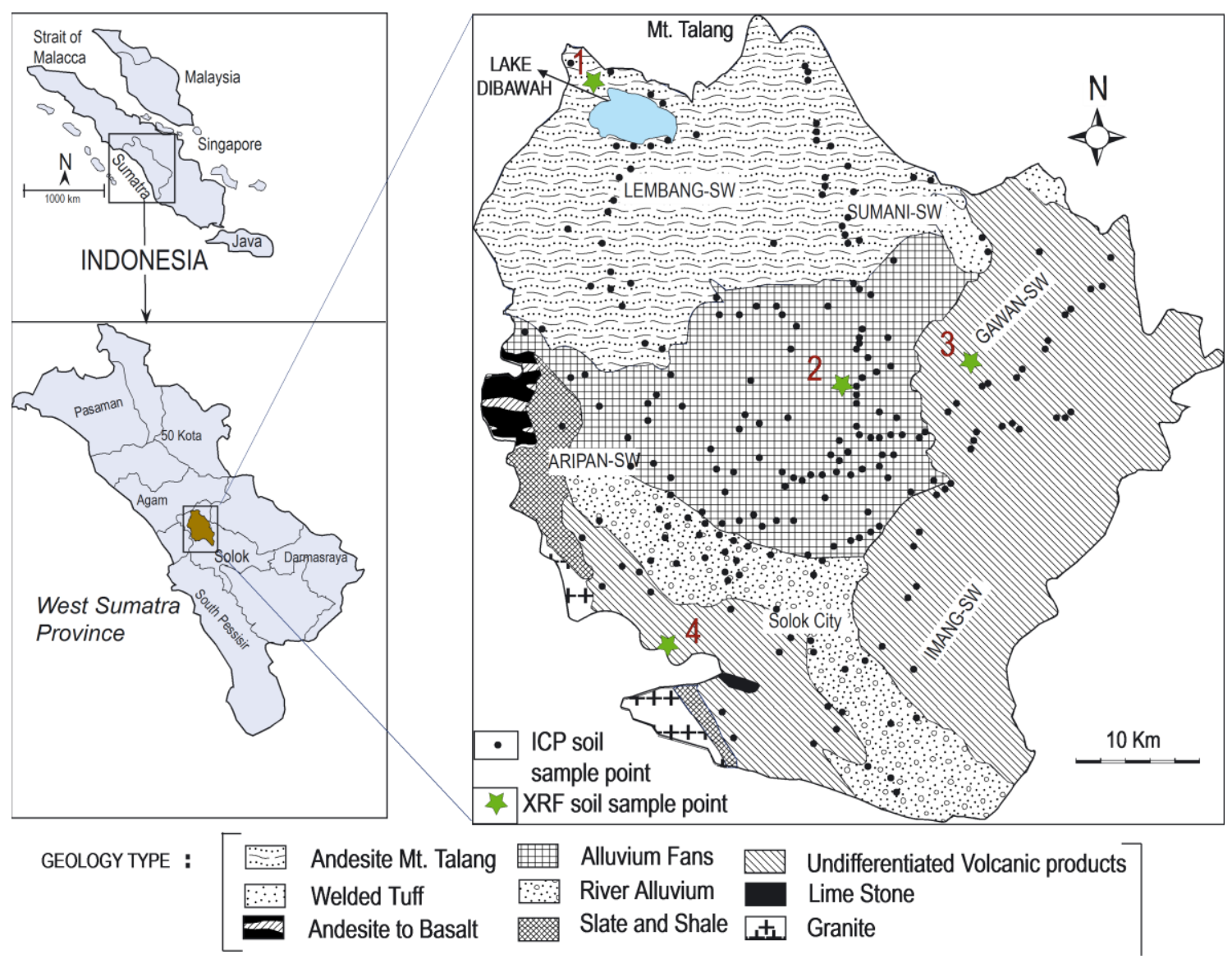

Figure 1. Study site, simplified basement geology and distribution of soil sampling points sites in Sumani watershed, West Sumatra, coordinates

Water from the upland rivers, tributaries, and Lake Dibawah accumulate in Singkarak Lake, and this carry municipal wastes and chemicals from agricultural land. Flatlands in the lowlands are used commonly for sawah, and the uplands for vegetable cultivation, although in some cases sawah and vegetables are rotated to maintain soil fertility and prevent pests. Lowland areas thus receive wastewater from irrigation sourced from Lake. Dibawah in the uplands. The drainages in the lowlands are urbanized, and house small industries such as Tofu and traditional food factories, and service industries such as car and motorcycle repair workshops and gasoline stands. TheSumani watershed contains arange of land crops, primarily trees such as coconuts, cloves, coffee, teak, mahogony, sawo (Achraszapota L.), avocados, melinjo (Gnetumgnemon), rubber, and cinnamon are planted in a combination with annual crops [27].
Chillies (Capsicum annum L.), onions (Allium cepa L.), soybeans (Glycine max L.), corn (Zea mays L.) and sweet potatoes (Ipomeabatatas L.) are the main crops in the vegetable gardens. uses, including primary forests, tree crop gardens (mixed gardens, coconuts and tea gardens), vegetable gardens, sawah, bush (shrubs, grasses and alangalang [land dominated by Imperatacylindrica (Poaceae)]) and settlements. Mixed garden refers to land where perennial

The Sumani watershed contains five sub-watersheds, including Sumani ,Lembang, Gawan, Aripan and Imang. Soil group distribution in the Sumani watershed consists of six groups i.e. Oxic Hapuldant, Andic Humitropept, Typic Kandiudult, Aeric Tropaquept, Typic Distropept and Typic Eutropept. The geology of the Sumani watershed area consists of the andesitic volcanic and intrusive rocks that form Mount Talang, undifferented volcanic products (basalt to andesite), slates and shales of the Tuhur Formation, 
limestones (Kuantan Formation) and surficial deposits consisting of river alluvium and alluvial fans [28, 29]. A block diagram showing geology feature and sampling location in watershed was generated by kriging topographic geology map using Surfer from Golden Software [30].

\subsection{Fields survey and analytical methods}

Soil surveys were conducted at 149 sites occupying a variety of geomorphic positions and land use types (Fig. 1). This paper discusses representative vegetable and sawah soils, and river sediments analyzed using X-ray fluorescence (XRF). Soils were collected at depths of $0-20 \mathrm{~cm}$, air dried, and sieved through a $2 \mathrm{~mm}$ mesh for physico-chemical analyses. Soil texture was determined by the pipette method [31]. Soil $\mathrm{pH}$ was measured using the glass electrode method with a soil: water ratio of 1:2.5 [32]. Exchangeable acidity was determined by first extracting with $1 \mathrm{~mol} \mathrm{L-1KCl}$ and titrating with $\mathrm{NaOH}[33]$. Extractable trace elements$\mathrm{Cd}, \mathrm{Pb}, \mathrm{Cu}$ and $\mathrm{Zn}$ were determined by first extracting with o.1 mol L-1 $\mathrm{HCl}$. Extractable trace element were determined using Inductively Coupled Plasma-Atomic Emission Spectroscopy (Shimadzu ICPS 2000, Kyoto, Japan) in the Soil and Ecological Laboratory, Shimane University. Exchangeable base cations ( $\mathrm{Ca}, \mathrm{Mg}, \mathrm{K}$ and $\mathrm{Na}$ ) were extracted using 1 mol L-1neutral ammonium acetate [34]. Exchangeable $\mathrm{Ca}$ and $\mathrm{Mg}$ were determined using Inductively Coupled Plasma-Atomic Emission Spectroscopy (Shimadzu ICPS 200o, Kyoto, Japan) and exchangeable K and $\mathrm{Na}$ were determined using Atomic Absorption Spectrophotometer (Shimadzu AS 680). Effective Cation Exchange Capacity (eCEC) represents the sum of the exchangeable bases and the exchangeable acidity. Four representative soil samples from upland, lowland, middle topography and river sediments were selected for XRF analysis. Dried samples were ground for $20 \mathrm{~min}$ in an automatic agate mortar and pestle. Selected major oxide $\left[\mathrm{TiO}_{2}, \mathrm{Fe}_{2} \mathrm{O}_{3}\right.$ (total iron expressed as $\mathrm{Fe}_{2} \mathrm{O}_{3}$ ), $\mathrm{CaO}, \mathrm{SiO}_{2}$ and $\left.\mathrm{P}_{2} \mathrm{O}_{5}\right]$ and trace element $(\mathrm{Pb}, \mathrm{Zn}, \mathrm{Cu}, \mathrm{Ni}, \mathrm{Cr}, \mathrm{V}, \mathrm{Sr}$, and $\mathrm{Rb})$ abundances were determined by XRF in the Department of Geoscience, Shimane University, using a RIX-20oo spectrometer (Rigaku Denki Co. Ltd.) equipped with Rh-anode X-ray tube. All samples were made on pressed powder disks, following [35]. Average errors for these elements are less than $\pm 10 \%$. Analytical results for USGS standard SCo-1 (Cody Shale) were acceptable compared with the proposed values of [36]. Contamination Factor (CF), Enrichment Factor (EF), Geo Accumulation Index (Igeo) [37, 38] and Pollution Load Index (PLI) [39, 40] were calculated to identify the environmental status of selected trace metals.

\section{Result and Discussion}

\subsection{Soil characteristics}

General characteristics and elemental abundances in the Sumani watershed are shown in Table 1. The Sumani watershed surface soils were mainly silty loams (55.8\%), and silty clay loams. Average $\mathrm{pH}$ values of the surface soils in the sawah, vegetable plots and river sediments were $4.90-5.85$, 4.96 and 5.34, respectively, indicating slightly acidic soil characteristics. The eCEC ranges between 9.17 to 15.32 $\mathrm{cmol} / \mathrm{kg}$ in Sawah; $17.83 \mathrm{cmol} / \mathrm{kg}$ in vegetable gardens and $13.99 \mathrm{cmol}(+) / \mathrm{kg}$ in river sediment, reflecting low to very high soil fertility conditions in agricultural lands in the Sumani watershed.

The watershed was mainly dominated by Sawah, vegetable gardens, mixed gardens and forest . Drainage patterns are good indicators of land form and bedrock type, and also suggest soil characteristics of the region. The predominant drainage pattern in the watershed is dendritic, indicating the existence of rocks with uniform resistance to erosion. Dendritic pattern is the irregular branching of channels ('tree like') in many directions, and is common in massive hard rock terrains, especially in metamorphic rocks, volcanic rocks, granitoids and in flat-lying areas. This pattern develops where rocks lack marked structural control, and have uniform resistance to erosion. The drainage network, physiography, geology type, of the watershed is illustrated in Fig 1 .

\subsection{Major and Trace element abundance}

Major and trace element analyses of the selected top soils (two sawah soils, one vegetable plot, and one stream sediment) in the Sumani watershed are given in Table 1. Because there is no standard criteria for heavy metal in agricultural soil in Indonesia, we compare the XRF data to modern sediment data from sediment columns sub ducting at trenches in Sumatra (Sumatra BCSCST), sediment columns sub ducting at trenches in Java (Java BCSCST),sediment columns sub ducting at trenches in E. Sunda (E.Sunda BCSCST), and sediment columns sub ducting at trenches in Japan (Japan BCSCST)[49], UCC (Bulk continental crust) from [46] and BCC (Bulk continental crust) from [42].The XRF results showed that the Sumani watershed soils average $30 \mathrm{mg} / \mathrm{kg} \mathrm{Pb}$ (Timbal), $55.75 \mathrm{mg} / \mathrm{kg} \mathrm{Zn(Zinc)}$ and $23 \mathrm{mg} / \mathrm{kg} \mathrm{Cu}$ (Cupper). The $\mathrm{Pb}$ content of Sumani watershed soils is similar to Sumatra, Java, E. Sunda and Japan BCSCST, but higher than BCC and UCC. However, concentrations of $\mathrm{Zn}$ and $\mathrm{Cu}$ are lower than Sumatra, Java, E. Sunda and Japan BCSCST (Table 1). Ni (Nickel) and $\mathrm{Cr}$ (Chromium) abundances range from 3 to 15 $\mathrm{mg} / \mathrm{kg}$ and 8 to $38 \mathrm{mg} / \mathrm{kg}$, while $\mathrm{Sr}$ (Strontium) range from 27 to $96 \mathrm{mg} / \mathrm{kg}$, indicating depletion relative to Sumatra 
BCSCST. Average $\mathrm{V}$ (Vanadium) and $\mathrm{Pb}$ concentrations in the Sumani watershed were $214.5 \mathrm{mg} / \mathrm{kg}$ and $37 \mathrm{mg} / \mathrm{kg}$, respectively. The concentration of $\mathrm{Rb}$ (Rubidium) in the upland vegetable soil, and $\mathrm{V}$

Table 1. Lithology and elemental concentration in the surface soil sample $(0-20 \mathrm{~cm})$ measured by XRF in Sumani watershed West Sumatra Indonesia

\begin{tabular}{|c|c|c|c|c|c|c|c|}
\hline \multirow[t]{2}{*}{$\begin{array}{l}\text { Area } \\
\text { (Code) }\end{array}$} & \multirow[t]{2}{*}{$\begin{array}{l}\text { code/ } \\
\text { Sample no. }\end{array}$} & \multicolumn{3}{|c|}{ Lithology } & \multicolumn{3}{|c|}{$\begin{array}{c}\text { Trace } \\
\text { elements } \\
(\mathrm{mg} / \mathrm{kg})\end{array}$} \\
\hline & & Type & $\mathrm{pH}$ & CEC & $\mathbf{P b}$ & Zn & $\mathbf{C u}$ \\
\hline \multirow{2}{*}{$\begin{array}{l}\text { Upland(1) } \\
\text { Middle(2) }\end{array}$} & Vegetable(1) & $\mathrm{Si}$ & 5,0 & 17,8 & 38 & 88 & 39 \\
\hline & $\begin{array}{l}\text { River } \\
\text { Sediment(2) }\end{array}$ & $\mathrm{L}$ & 5,3 & 14,0 & 30 & 62 & 36 \\
\hline Side (3) & Sawah(3) & $\mathrm{C}$ & 5,9 & 9,2 & 33 & 44 & 11 \\
\hline Lower(4) & Sawah(4) & $\mathrm{L}$ & 4,9 & 15,3 & 19 & 34 & 6 \\
\hline \multirow{2}{*}{\multicolumn{2}{|c|}{$\begin{array}{l}\text { Sumatra BCSCST } \\
\text { Java BCSCST }\end{array}$}} & & & 14,1 & 25 & 96 & 39 \\
\hline & & & & & 26 & 100 & 122 \\
\hline \multicolumn{2}{|c|}{ E. Sunda BCSCST } & & & & 21 & 82 & 163 \\
\hline \multicolumn{2}{|c|}{ Japan BCSCST } & & & & 24 & 77 & 89 \\
\hline \multicolumn{2}{|l|}{$\mathrm{BCC}$} & & & & 13 & 73 & 24 \\
\hline UCC & & & & & 20 & 71 & 2 \\
\hline
\end{tabular}

Table 1. Continued

\begin{tabular}{lllllll}
\hline Area & code/ & \multicolumn{5}{c}{ Trace elements (mg/kg) } \\
\cline { 3 - 7 } (Code) & Sample no. & Ni & Cr & V & Sr & Rb \\
\hline Upland(1) & Vegetable(1) & 3 & 8 & 101 & 96 & 98 \\
Middle(2) & River & 9 & 22 & 294 & 65 & 12 \\
& Sediment(2) & 9 & & & & \\
Side (3) & Sawah(3) & 12 & 24 & 277 & 27 & 14 \\
Lower(4) & Sawah(4) & 15 & 38 & 186 & 47 & 24 \\
& Mean & 10 & 23 & 215 & 59 & 37 \\
Sumatra BCSCST & 58 & 102 & 90 & 251 & 45 \\
Java BCSCST & 92 & 71 & 118 & 218 & 8 \\
E. Sunda BCSCST & 64 & 44 & 96 & 405 & 63 \\
Japan BCSCST & 67 & 37 & 84 & 87 & 60 \\
BCC & 51 & 119 & 131 & 325 & 58 \\
UCC & 20 & 35 & 60 & 350 & 112 \\
\hline
\end{tabular}

in sawah soil were roughly double the level in Sumatra BCSCST , suggesting enrichment in the weathered parent rocks of the soils. Average $\mathrm{SiO}_{2}, \mathrm{CaO}_{2}$ and $\mathrm{P}_{2} \mathrm{O}_{5}$ abundances in the Sumani watershed soils were lower than Sumatra BCSCST.

In contrast, contents of $\mathrm{TiO}_{2}$ and $\mathrm{Fe}_{2} \mathrm{O}_{3}$ were almost double that of Sumatra BCSCST, UCC and BCC. Average values of $\mathrm{SiO}_{2}, \mathrm{TiO}_{2}, \mathrm{Fe}_{2} \mathrm{O}_{3}, \mathrm{CaO}$ and $\mathrm{P}_{2} \mathrm{O}_{5}$ were 49.9, 1.o, 8.22, 0.4 and $0.09 \mathrm{wt} \%$, respectively, broadly similar to Sumatra BCSCST, Java BCSCST, E. Sunda BCSCST, Japan BCSCST, UCC and BCC (Table 1).
Table 1. Continued

\begin{tabular}{|c|c|c|c|c|c|c|}
\hline \multirow{2}{*}{$\begin{array}{l}\text { Area } \\
\text { (Code) }\end{array}$} & \multirow{2}{*}{$\begin{array}{l}\text { code/ } \\
\text { Sample no. }\end{array}$} & \multicolumn{5}{|c|}{ Major oxides (wt.\%) } \\
\hline & & $\mathrm{SiO}_{2}$ & $\mathrm{TiO}_{2}$ & $\mathrm{Fe}_{2} \mathrm{O}_{3}$ & $\mathrm{CaO}$ & $\mathrm{P}_{2} \mathrm{O}_{5}$ \\
\hline Upland(1) & Vegetable(1) & 53 & 0,56 & 1,9 & 0,66 & 0,16 \\
\hline Middle(2) & $\begin{array}{l}\text { River } \\
\text { Sediment(2) }\end{array}$ & 40 & 1,14 & 15,3 & 0,27 & 0,07 \\
\hline Side (3) & Sawah(3) & 42 & 1,08 & 10,1 & 0,18 & 0,10 \\
\hline \multirow[t]{2}{*}{ Lower(4) } & $\operatorname{Sawah}(4)$ & 65 & 1,22 & 5,5 & 0,47 & 0,02 \\
\hline & Mean & 50 & 1,00 & 8,2 & 0,40 & 0,09 \\
\hline \multicolumn{2}{|c|}{ Sumatra BCSCST } & 63 & 0,69 & 5,0 & 3,16 & 0,15 \\
\hline \multicolumn{2}{|c|}{ Java BCSCST } & 60 & 0,71 & 5,9 & 2,71 & 0,19 \\
\hline \multicolumn{2}{|c|}{ E. Sunda BCSCST } & 54 & 0,59 & 5,0 & 9,06 & 0,13 \\
\hline \multicolumn{2}{|c|}{ Japan BCSCST } & 69 & 0,35 & 3,8 & 0,65 & 0,20 \\
\hline \multicolumn{2}{|l|}{$\mathrm{BCC}$} & 59 & 0,70 & 6,6 & 6,40 & 0,20 \\
\hline \multicolumn{2}{|l|}{ UCC } & 66 & 0,5 & 5 & 4,2 & 0,16 \\
\hline
\end{tabular}

BCSCST, Bulk composition sediment columns sub dicting at trenches [5o]; BCC, Bulk continental crust from [42]; Si, Silty; C, Clay, L, Loam; UCC, upper continental crust measured by XRF from [46],

The average concentration of $\mathrm{Pb}$ in all the land use types (Sawah(SW), Mixed garden(MG), Shrub(Sh), Forest(F), Tea(T), Settlement(St),Vegetable(Vg) and River sediment(Rs)) has greater values than, non contaminated soil in Japan $(\mathrm{NCJ})(\mathrm{Pb} 2.7 \mathrm{mg} / \mathrm{kg} ; 45.9 \%$ of total sample), but lower than contaminated soil in Japan(CSJ) (Pb 6o g/kg; $6.8 \%$ of total sample). The average concentration of $\mathrm{Cu}$ in all the land use types (SW, MG, Sh,F, T, St,Vg ) has lower values than NCJ ( Zn $11 \mathrm{mg} / \mathrm{kg}$; 90.5\% of total sample), but $\mathrm{Cu}$ concentration at Rs was mostly similar to NCJ. The average concentrations of $\mathrm{Cu}$ at $\mathrm{MG}, \mathrm{Sh}, \mathrm{F}, \mathrm{T}, \mathrm{St}, \mathrm{Vg}$ were lower than value of Non- Contaminated soil in Japan (NCJ, $\mathrm{Cu} \quad 2.9 \mathrm{mg} / \mathrm{kg} ; 67.1 \%$ of total sample) but average concentration of $\mathrm{Cu}$ at SW, St, Rs lower than CSJ (Cu 6.1 $\mathrm{mg} / \mathrm{kg}$ ) (Table 2). 
Table 2 Lithology and elemental concentration in the surface soil sample $(0-20 \mathrm{~cm})$ measured by ICP in Sumani watershed West Sumatra Indonesia

\begin{tabular}{llllll}
\hline $\begin{array}{l}\text { Area } \\
\text { (Code) }\end{array}$ & code/ Sample & \multicolumn{4}{c}{ Lithology } \\
& no. & n & Type & pH & CEC \\
\hline Upland(1) & Vegetable(Vg) & 4 & Si & 4,7 & 17,7 \\
Middle(2) & River & 6 & L & 5,8 & 29,0 \\
& Sediment(Rs) & & & & \\
Side (3) & Sawah(Sw) & 79 & C & 5,5 & 21,7 \\
Lower(4) & Shrub(Sh) & 7 & L & 5,6 & 19,3 \\
& Forest(F) & 8 & SL-L & 5,6 & 20,1 \\
& Settlement(St) & 2 & SL-L & 5,8 & 27,8 \\
& Tea(T) & 2 & SL-L & 5,3 & 13,5 \\
& Mixed & & SL-L & 5,5 & 21,1 \\
Sumani & garden(MG) & 41 & & & \\
Watershed & Mean & & & 5,5 & 21,3 \\
NSJ & Mean & & SL-L & 5,6 & \\
CSJ & Mean & & SL-L & 5,0 & \\
\hline
\end{tabular}

Table 2 Continued

\begin{tabular}{|c|c|c|c|c|}
\hline \multirow[t]{2}{*}{$\begin{array}{l}\text { Area } \\
\text { (Code) }\end{array}$} & \multirow[t]{2}{*}{$\begin{array}{l}\text { code/ Sample } \\
\text { no. }\end{array}$} & \multicolumn{3}{|c|}{ Trace elements (mg/kg) } \\
\hline & & $\mathbf{P b}$ & Zn & $\mathrm{Cu}$ \\
\hline Upland(1) & Vegetable(Vg) & 13,0 & 7,8 & 1,8 \\
\hline Middle(2) & $\begin{array}{l}\text { River } \\
\text { Sediment(Rs) }\end{array}$ & 11,3 & 11,5 & 3,1 \\
\hline Side (3) & $\operatorname{Sawah}(\mathrm{Sw})$ & 5,1 & 3,4 & 25,9 \\
\hline Lower(4) & Shrub(Sh) & 4,8 & 1,7 & 1,1 \\
\hline & Forest $(\mathrm{F})$ & 5,2 & 3,1 & 1,1 \\
\hline & Settlement(St) & 2,5 & 6,6 & 3,2 \\
\hline & Tea(T) & 8,5 & 2,8 & 2,2 \\
\hline & $\begin{array}{l}\text { Mixed } \\
\text { garden(MG) }\end{array}$ & 3,4 & 7,5 & 1,9 \\
\hline $\begin{array}{l}\text { Sumani } \\
\text { Watershed }\end{array}$ & Mean & 6,7 & 5,6 & 5 \\
\hline NSJ & Mean & 2,7 & 11 & 2,9 \\
\hline CSJ & Mean & 60 & 151 & 6,1 \\
\hline
\end{tabular}

Si, Silty; C, Clay, L, Loam, SL. Silt Loam; NCJ, non conataminated soil in Japan measured extracting with $0.1 \mathrm{~mol} \mathrm{L-1}$ HCL and measured by ICP from [51]; CSJ, contaminated soil in Japan from [51]

\subsection{Soil and sediment quality guidelines}

The pollution status (non-polluted, moderately polluted, or heavily polluted) of the four soil samples taken at sawah and vegetable area and river sediment was evaluated based on sediment quality guidelines compared to background concentrations [41]. The XRF data show significant enrichment in $\mathrm{Pb}$ compared to $\mathrm{BCC}$ and UCC. Concentrations of $\mathrm{Zn}$ and $\mathrm{Cu}$ in the vegetable areas are significantly enriched compared to BCC and UCC (Table 1 ).

\subsection{Assessment of metal pollution}

The degree of pollution in sediments and soil can be assessed by determining the parameters CF, EF, PLI and Igeo. In the present study, these pollutant indicators were calculated based on average BCC (Bulk continental crust) from [42]. The different methods are discussed below.

\subsubsection{Contamination Factor (CF)}

The geochemical compositions of soils are a powerful tool for environmental diagnosis, as well as identifying contamination point sources and non-point sources and permitting monitoring. The level of contamination is expressed by a CF [43] that estimates the impact scales or ranges, and converts the calculated numerical results into broad descriptive bands of pollution ranging from low to high intensity. The CF suggested by [44] was used to describe the concentration of given toxic substance in a basin:

\section{$\mathrm{CF}=\mathrm{Co} \_\mathrm{l} / \mathrm{Cn}$}

where $\mathrm{Co}^{-1}$ is the mean content of the substances and $\mathrm{Cn}$ are the background values according to [42]. "The CF may indicate low contamination $(\mathrm{CF}<1)$; moderate contamination $(1<\mathrm{CF}<3)$; considerable contamination $(3<\mathrm{CF}<6)$; or very high contaminations $(\mathrm{CF}>6)$ " [44].

The CF values (Table 3) for $\mathrm{Pb}$ range from 1.51 in Sawah sample 4 to 3.02 in the vegetable soil, suggesting moderate to considerable contamination at this site. Zinc has an $\mathrm{CF}$ of $>1$ in the vegetable soil, but values of $<1$ in all others, whereas $\mathrm{CuCF}$ is $>1$ in the vegetable soil and the stream sediment, and $<1$ in the sawah soils. $\mathrm{CF}$ values for $\mathrm{Ni}$ and $\mathrm{Cr}$ are $<1$ in all samples, indicating nil or low contamination of these elements (Table 3). Vanadium CF is also $<1$ in the vegetable soil, but ranges from 1.42-2.24 in the other samples. The high $\mathrm{CFs}$ for $\mathrm{Pb}, \mathrm{Zn}$ and $\mathrm{Cu}$ in the vegetable soil may be due to the influence of external discrete sources like scavenging and agricultural runoff, erosion, residue of pesticide, fertilizer and manure applied by farmers. [29] report that volcanic ash from Mount Talang contains trace elements that include $\mathrm{Pb}(16.5-27.50 \mathrm{mg} / \mathrm{kg}), \mathrm{Zn}(64.88$ $90.60 \mathrm{mg} / \mathrm{kg})$ and $\mathrm{Cu}(21.2-38.5 \mathrm{mg} / \mathrm{kg})$, and this material may also constitute a source of these elements. With one exception, $\mathrm{CF}$ values for the non-metallic elements $\mathrm{Sr}$ and $\mathrm{Rb}$ are $<1$, indicating normal levels in the soils. 


\subsubsection{Pollution Load Index (PLI)}

The pollution level of trace metals was calculated based on PLI [39] that reveal the geometric mean CF of each of its constituent samples present in the study area. The PLI is computed by the formula:

$$
\mathrm{PLI}=\mathrm{n}\left(\mathrm{CF}_{1 x} \mathrm{CF}_{2 \mathrm{x}} \mathrm{CF}_{3} \mathrm{x} \ldots \ldots \mathrm{XCFn}\right)^{\wedge} \mathrm{O} .5
$$

where $\mathrm{CF}$ is the contamination factor and $\mathrm{n}$ is the number of selected metals. According to [39], PLI values of o, 1, or >1 suggest the absence of baseline pollutants, their presence, and progressive deterioration of sediment quality, respectively. The low PLI values for all four surface samples in both sawah and vegetable plot indicate pollutants are not present (Table 3).

Table 3. CF and PLI value at representative land use type in Sumani watershed

\begin{tabular}{llllllll}
\hline Area & code/ & \multicolumn{6}{c}{ Contamination factor } \\
\cline { 3 - 8 } (Code) & Sample no. & Type & Pb & Zn & Cu & Ni & Cr \\
\hline Upland(1) & Vegetable(1) & $\mathrm{Si}$ & 3,0 & 1,2 & 1,6 & 0,06 & 0,1 \\
Middle(2) & River & & & & & & \\
& Sediment(2) & $\mathrm{L}$ & 2,4 & 0,8 & 1,5 & 0,18 & 0,2 \\
Side (3) & Sawah (3) & $\mathrm{C}$ & 2,6 & 0,6 & 0,5 & 0,24 & 0,2 \\
Lower(4) & Sawah (4) & $\mathrm{L}$ & 1,5 & 0,5 & 0,3 & 0,29 & 0,3 \\
& Mean & & 2,38 & 0,8 & 1,0 & 0,19 & 0,2 \\
\hline
\end{tabular}

Table 3. Continued

\begin{tabular}{lllllll}
\hline $\begin{array}{l}\text { Area } \\
\text { (Code) }\end{array}$ & code/ & \multicolumn{6}{c}{ Contamination factor } & PLI \\
\cline { 4 - 7 } & Sample no. & Type & V & Sr & Rb & \\
\hline Upland(1) & Vegetable(1) & Si & 0,77 & 0,30 & 1,69 & 0,004 \\
Middle(2) & River & & & & & \\
& Sediment(2) & L & 24 & 0,20 & 0,21 & 0,000 \\
Side (3) & Sawah (3) & $\mathrm{C}$ & 2,11 & 0,08 & 0,24 & 0,000 \\
Lower(4) & Sawah (4) & $\mathrm{L}$ & 1,42 & 0,14 & 0,41 & 0,000 \\
& Mean & & 1,64 & 0,18 & 0,64 & 0,001 \\
\hline
\end{tabular}

\subsubsection{Enrichment Factors (EF)}

Heavy metal enrichment factors have been proposed as indicators for diffuse soil contamination. The behavior of a given element in soil (that is, the determination of its accumulation or leaching) may be established by comparing concentrations of a trace element with a reference element [45]. In this study, the EF was also used to assess the level of contamination and possible anthropogenic impacts on the soils in the Sumani watershed. To measure the anomalous metal concentrations, $\mathrm{TiO}_{2}$ was employed as the normalizer to calculate EF values and Igeo because it has a short residence time and low concentration in natural waters, and thus is transferred quantitatively from source to sediments and soil [46]. It is also unlikely to be contributed by anthropogenic activity. The EF is calculated as:

$\mathrm{EF}=\left(\mathrm{M} / \mathrm{TiO}_{2}\right.$ sample $) /\left(\mathrm{M} / \mathrm{TiO}_{2}\right.$ background $) ;$ where $\left(\mathrm{M} / \mathrm{TiO}_{2}\right)$ sample is the ratio of metal and $\mathrm{TiO}_{2}$ concentrations of the sample and $\left(\mathrm{M} / \mathrm{TiO}_{2}\right)$ background is the ratio of metal and $\mathrm{TiO}_{2}$ concentrations of the background. As regional geochemical background values are not available, average concentrations of $\mathrm{Pb}, \mathrm{Zn}, \mathrm{Cu}, \mathrm{Ni}, \mathrm{Cr}$, $\mathrm{V}$, BCC [42] were used in this study. Generally, the enrichment factor is used to assess soil contamination (enrichment) based on these criteria: EF < 2-depletion to minimal enrichment; EF 2-5-moderate enrichment; EF 520-significant enrichment; EF 20-40-very high enrichment; EF > 40-extremely high enrichment. EF can also be used to evaluate elemental depletions in soils. EF values of less than 1 may indicate that leaching and consumption of elements take precedence over their accumulation in soil [47].

The EF values for $\mathrm{Zn}, \mathrm{Cu}, \mathrm{Ni}, \mathrm{Cr}, \mathrm{Sr}$ and $\mathrm{Rb}$ in the sawah soils indicate depletion to minimal enrichment $(\mathrm{EF}<2)$, as shown in Fig. 2. This shows no significant enrichment has occurred, and may indicate that leaching and consumption over accumulation in the soils [47]. Sediment input from the uplands is the main control on the abundances of these element. EF values $<2$ strongly suggest that $\mathrm{Zn}, \mathrm{Cu}, \mathrm{Ni}, \mathrm{Cr}$, $\mathrm{Sr}$ and $\mathrm{Rb}$ in the sawah soils originate from natural processes. However, the EF values for $\mathrm{Pb}, \mathrm{V}$, in the vegetable soil and river sediment show moderate enrichment (EF, 25). For $\mathrm{Pb}$ this could indicate contribution from both human activities (agrochemicals and leaded petrol from vehicles) and natural sources (volcanic ash) as noted by [15, 29]. The low $\mathrm{EF}$ values for $\mathrm{Zn}, \mathrm{Cu}, \mathrm{Ni}, \mathrm{Cr}$, and $\mathrm{Sr}$ are classed as depletion to minimal enrichment, suggesting that no environmental problem exists.

\subsubsection{Index of geoaccumulation (Igeo)}

The Igeo was also calculated to determine the level of pollution, using the following equation [48]:

Igeo $=\log _{2}(\mathrm{Cn} / 1.5 \mathrm{Bn})$,

where $\mathrm{Cn}$ is the measured concentration of the element $\mathrm{n}$ and $\mathrm{Bn}$ is the geochemical background value of element $\mathrm{n}$ in BCC [49]. The factor 1.5 is introduced to include possible variations in the background values due to lithogenic effects. The following classification is given for Igeo[48]: $<0=$ practically unpolluted, $\mathbf{0}-\mathbf{1}=$ unpolluted to moderately polluted, $1-2=$ moderately polluted, 2-3=moderately to strongly polluted, 3-4= strongly polluted, 4-5=strongly to extremely polluted, and $>5=$ extremely polluted.

The Igeo values of $<0$ for $\mathrm{Zn}, \mathrm{Cu}$, and $\mathrm{Ni}$ in the sawah soils and the river sediment (Figure 3 ) confirm that the areas are unpolluted by these metals, as shown by the indicators discussed above. Furthermore, the Igeo values for $\mathrm{Pb}$ all lie in the range from o to 1 , suggesting that the soils are unpolluted to at worst only moderately polluted by this 
metal. The highest Igeo values for $\mathrm{Pb}, \mathrm{Cu}$, and $\mathrm{Zn}$ occur in the vegetable plot upland soil, suggesting that agricultural practices may be beginning to influence the soils. However, a much larger soil database and well-defined background values for the basement rocks are needed before this can be confirmed. The HFSE (high field strength elements) also show slightly elevated Igeovalues. Similar results for $\mathrm{CF}$ and EF were obtained, but the immobile nature of these elements preclude an anthropogenic source

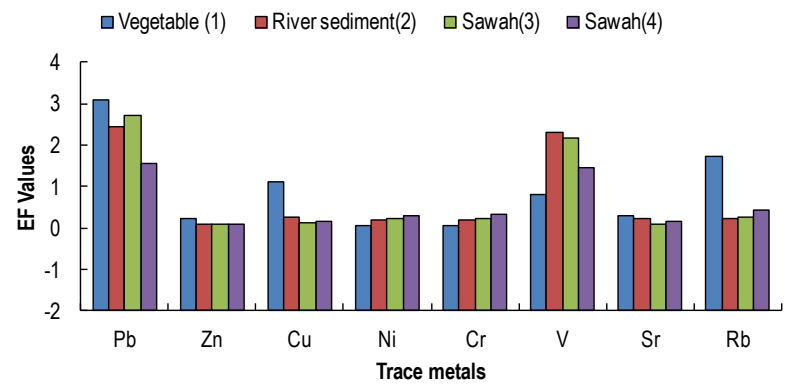

Figure 2. EF values in Vegetable, River sediment and sawah in Sumani watershed

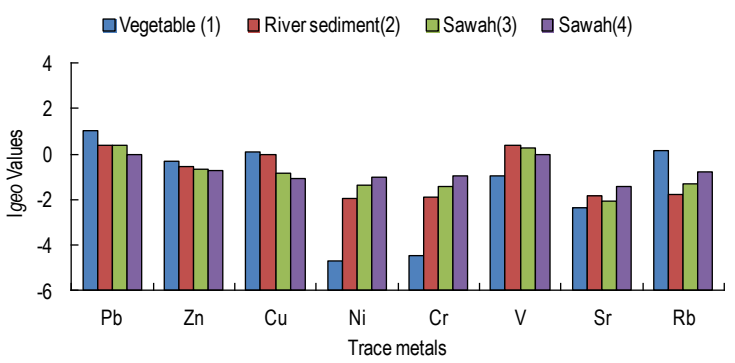

Figure 3 Igeo values in Vegetable, River sediment and sawah in Sumani watershed.

\section{Conclusion}

Soils of Sumani watershed have slight acid to acid $\mathrm{pH}$, and based on their CEC, samples ranged from low to very high soil fertility conditions in agriculture land. In Sumani watershed, representative soil sample at River sediment, sawah and vegetable area analyzed by XRF showed that concentration of $\mathrm{Pb}$ are greater than those of BCC and UCC and concentration of $\mathrm{Pb}$ and $\mathrm{Zn}$ at Vegetable and River sediment greater than Sumatra BCSCST. The elevated CF values are probably the result of anthropogenic activity and provide a useful means of distinguishing between natural and anthropogenic metals entering the surface soil in Sumani watershed. The PLI values confirm that the quality of the soil at sawah, vegetable and river sediment area in Sumani watershed has no pollutant, and this may not impact on crop production, human life and other organism. According to the EF and the Igeo Index, the area can be considered as having considerable contaminant by $\mathrm{Pb}$ and moderate contaminant by $\mathrm{Zn}, \mathrm{Cu}, \mathrm{Rb}$, at vegetables area. Sawaharea can be considered as having moderate contamination by $\mathrm{Pb}, \mathrm{Cu}$ and $\mathrm{V}$ and low contaminated or uncontaminated with respect $\mathrm{Zn}, \mathrm{Cu}, \mathrm{Ni}, \mathrm{Cr}, \mathrm{Sr}$ and $\mathrm{Rb}$. Concentration $\mathrm{Pb}$ and $\mathrm{Cu}$, in surface soil at vegetables and sawah area in Sumani watershed reflected the tendency of metal contamination that seem to be related to nature additional of volcanic ash from mount Talang, organic matter-rich through agricultural practices and anthropogenic point sources such as fertilizer and pesticide residue and gas from vehicle.

\section{Acknowledgements}

We thank Professor Tsugiyuki Masunaga of Shimane University, Japan, for their invaluable help during soil analysis, and many helpful suggestions. We are also grateful to KEM.RISTEK.DIKTI Indonesia for their support in this research.

\section{References}

[1] Madrid L, Díaz-Barrientos E, Madrid F. Distribution of heavy metal contents of urban soils in parks of Seville. Chemos;2002, 49:1301-1308.

[2] Shayed Hafizurrahman, Khanan D, Adyel TM, Islam MS, Ahsan MA, Akbor MA. Assessment of heavy metal Contamination of Agricultural Soil around Dhaka Export Processing Zone (DEPZ), Bangladesh: implication of Seasonal variation and Indices. ApplSci; 2012, 2: 584-601.

[3] Suzuki S, Djuangshi N, Hyodo K, Soemarwoto O . Cadmium, Copper, and Zinc in Rice produced in Java. Arch. Envoron Toxicol; 1980, 9: 43-449.

[4] He QB, Singh BR. Plant availability of cadmium in soils. I. Extractable cadmium in newly and long-term cultivated soils. Acta Agric Scand Sect B Soil Plant Sci; 1993, 43: 134-141

[5] Buschmann J, Berg M, Stengel C, Winkel L, Sampson ML, Trang PTK Viet PH. Contamination of drinking water resources in the Mekong delta floodplains: arsenic and other trace metals pose serious health risks to population. Environ;2008, 134:756-764

[6] Arnason JG, Fletcher BA . A 40+ year record of Cd, $\mathrm{Hg}, \mathrm{Pb}$, and $\mathrm{U}$ deposition in sediments of Patroon Reservoir, Albany County, NY, USA. Environ Pollut; 2003, 123: 383-391

[7] Zvinowanda C M, Okonkwo JO, Shabalala PN, Agyei NM. A novel adsorbent for heavy metal remediation in aqueous environments. IJ Environ SciTechnol;2009,6: 425-434.

[8] Adams RH, Guzman OFJ, Zavala CJ. Water repellency in oil contaminated sandy and clayey soils. I J Environ SciTechnol; 2008, 5(4): 445-454.

[9] Yang H, Rose NL, Batterbee RW. Distributions of some trace metals in Lochnagar, a Scottish mountain lake ecosystem and its catchment. Sci Total Environ;2002, 285: 197-208.

[10] Aktar MW, Paramasivam M, Ganguly M, Purkait S, SenguptaD. Assessment and occurrence of various heavy metals in surface water of Ganga River around Kolkata: A study for toxicity and ecological impact. Environ Monit Assess; 2010, 160: 207-213. 
[11] Agbozu IE, Ekweozor IKE, Opuene K. Survey of heavy metals in the catfish Synodontisclarias. I J Environ SciTechnol;2007, 4(1) : 93-98.

[12] Nicolau R, Galera-Cunha A, Lucas Y. Transfer of nutrients and labile metals from the continent to the sea by a small Mediterranean river. Chemos; 2006, 63(3): 469-476.

[13] Otero N, Vitoria L, Soler A, Canals A. Fertilisercharacterisation: major, trace and rare earth elements. ApplGeochem; 2005, 20: $1473-1488$.

[14] D’Ascoli R, Rao MA, Adamo P, Renella G, Landi L, Rutigliano FA, Terribile F, Gianfreda L. Impact of river overflowing on trace element contamination of volcanic soils in south Italy part II: soil biological and biochemical properties in relation to trace element speciation. Environ Pollut;2006, 144:317-326.

[15] Praveena SM, Ahmed A, Radojevic M, Abdullah MH, Ariz AZ. Multivariate and Geoaccumulation Index Evaluation in Mangrove Surface Sediment of Mengkabong Lagoon, Sabah. Bull Environ Contain Toxicol;2008, 81: 52-56

[16] Amin B, Ismail A, Arshad A, Yap CK, Kamaruddin MH. Anthropogenic impacts on heavy metal concentrations in the coastal sediments of Dumai, Indonesia. Environ Monit Assess;2009, 148: 291-305.

[17] Ahmed F, Bibi MH, Fukushima T, Seto K, Ishiga H, Fukushima T. Abundances, distribution, and sources of trace metals in Nakaumi-Honjo coastal lagoon sediments, Japan. Environ Monit Assess;2010, 167: 473-491.

[18] Mapandaa FE, Mangwayanaa N, Nyamangaraa J, Giller KE. The effect of long-term irrigation using wastewater on heavy metal contents of soils under vegetables in Harare, Zimbabwe. AgriEcosys Environ;2005, 107: 151-165.

[19] Muchuweti MA, Ndhlala R, Kasiamhuru A.Analysis of phenolic compounds including tannins, gallotannins and flavanols of Uapacakirkiana fruit. Food Chem; 2006, 94: 415-419.

[20] Van Rotterdam-Los AMD, Heikens A, Vriend SP, van Bergen MJ, van Gaans RFM. Impact of acid effluent from KawahIjen Crater Lake on irrigated agricultural soils: soil chemical processes and plant uptake. J VolcanolGeotherm Res;2008a, 178:287-296.

[21] Darmawan, SyafrimenYasin, KazutakeKyuma, TsugiyukiMasunaga, Toshiyuki Wakatsuki. The Long-term Changes in Heavy Metals Content of Sawah Soil in Relation to Land Management and Cultivation Intensity. Pedologist;2010, 108-117

[23] Herawati. N, S. Suzuki, K. Hayashi, I. F. Rivai, H. Koyama. Cadmium, Copper, and Zinc Levels in Rice and Soil of Japan, Indonesia, and China by Soil Type. Bull. Environ. Contam. Toxicol;200o, 64:33-39.

[24] Aflizar, Saidi A, Husnain, Ismawardi, Istijono B, Harmailis, Somura H, Wakatsuki T and Masunaga T . A land use planning recommendation for the Sumani watershed, West Sumatera, Indonesia .Tropics; 2010a, 19: 43-51.

[25] Aflizar, Saidi A, Husnain, Indra R, Darmawan, Harmailis, Somura H, Wakatsuki T, Masunaga T. Soil erosion characterization in an agricultural watershed in West Sumatra, Indonesia. Tropics; 2010b, 19: 29-42.

[26] Wakatsuki T, Shinmura Y, Otoo E, Olaniyan GO . Africanbased sawah system for the integrated watershed management of the small inland valley of West Africa. FAO Water Report; 1998, No. 17. p. 5-79.

[27] Karyono. Home garden in Java: their structure and function. In: Tropical Home Garden (Eds. Lan-dauer, K., Brazil, M.),The
United Nations University Press, Tokyo; 1990, p. 138-146.

[28] Indonesia Geological Research and Development Centre. Systematic Geological map of the Solok, quadrangle Sumatra.0815. Scale: 1:250000 edition 2 by PH silitonga and Kastowo. Base map by U.S. Army Map service, series T503;1995, (index number, SA 47-4). Index showing quadrangle names and number according to national coordination agency for surveys and mapping (NCSAM), 1975.

[29] Fiantis D, Nelson M, Shamsuddin J, Goh TB, Van Ranst E. Determination of the Geochemical Weathering Indices and Trace Element Content of new Volcanic Ash deposits from Mt. Talang west Sumatra) Indonesia. Eurosian Soil Sci; 2010, 43(13) : $1477-1485$.

[30] Golden Software. SURFER 9 for windows. Golden, Colorado. 2010. Available from URL: http://www.goldensoftware.com/products/surfer/surfer.shtml.

[31] Gee GW, Bauder JW. Particle-size Analysis. In: Methods of Soil Analysis, Part 2. Physical and Mineralogical Methods, (eds. Klute, A.), American Society of Agronomy and Soil Science Society of America, Madison, Wisconsin; 1986, p. 399-404.

[32] IITA. Selected Methods for Soils and Plant Analysis, Manual Series No. 5, IITA, Ibadan, Nigeria; 1979, pp. 70.

[33] McLean EO. Soils $\mathrm{pH}$ and lime requirement. In Methods of Soils Analysis, Number 9, Part 2, Ed. AL Page; 1982, pp. 199209. ASA, SSSA, Madison.

[34] Thomas GW. Exchangeable cations. In Methods of Soils Analysis, Number 9, Part 2, Ed. AL Page;1982, pp. 159-165. ASA, SSSA, Madison.

[35] Ogasawara M. Trace element analysis of rock samples by X-ray fluorescence spectrometry, using Rh anode tube. Bull Geol Sur Jpn;1987, 38(2): 57-68.

[36] Potts, P. J., Tindle, A. G., \& Webb, P. C.. Geochemicalreference material compositions. 1992 (p. 313). Caithness:Whittles.

[37] Reddy MS, Basha S, Kumar VGS, Joshi HV, Ramachandraiah G. Distribution, enrichment and accumulation of heavy metals in coastal sediments of Alang-Sosiya ship scrapping yard, India. Mar Pollut Bull;2004, 48:1055-1059.

[38] Rahman MA, Ishiga H. Trace metal concentrations in tidal flat coastal sediments,Yamaguchi Prefecture, southwest Japan. Environ Monit Assess;2012, 184: 5755-5771.

[39]Tomlinson DC, Wilson JG, Harris CR, Jeffrey DW. Problems in the assessment of heavy-metal levels in estuaries and the formation of a pollution index. Helgoland Mar Res; 1980, 3: 566575 .

[40] Ray AK, Tripathi SC, Patra S, Sarma VV. Assessment of Godavary estuarine mangrove ecosystem through trace metal studies. Environ I; 2006, 32:219-223.

[41] Rubio B, Nombela MA, Vilas F. Geochemistry of major and trace elements in sediments of the Ria de Vigo (NW Spain): An assessment of metal pollution. Mar Pollut Bull;200o, 40(11): 968-980.

[42] Rudnick RL, Fountain DM. Nature and composition of the continental crust: a lower crustal perspective. Rev Geophys;1995, 33(3): 267-309

[43] Salomons W, Forstner U. Metals in hydrocycleBerlin: Springer; 1984, pp.63-98.

[44] Hakanson L. An ecological risk index for aquatic pollution control a sedimentological approaches. Water Res;1980, 14:9751001.

[45] Kabata-Pendias A, Pendias H. Trace elements in soils and plants. CRC Pres, Inc. Boca Raton, 1985 Florida. 
[46] Taylor SR, McLennan SM. The continental crust: Its composition and evolution. Oxford;1985, Blackwell.

[47] Loska K, Wiechuła D, Pelczar J. Application of enrichment factor to assessment of zinc enrichment/depletion in farming soils. Commun Soil Sci Plant Anal; 2005, 36: 1117-1128.

[48] Muller G. Index of geoaccumulation in the sediments of the Rhine River. Geol J; 1969, 2: 108-118.

[49] Rudnick RL, Gao S. The crust. In H. D. Holland \& K. K. Turekian (Eds.), Treatise on geochemistry; 2005, 3 (p. 537). Oxford: Elsevier Science

[50] Plank T, Langmuir $\mathrm{CH}$. The chemical composition of subducting sediment and its consequences for the crust and mantle. ChemGeol; 1998, 145: 325-394.

[51] KashemM. A.; SinghB. R.; KondoT.; ImamulHuqS. M.; KawaiS. Comparison of extractability of $\mathrm{Cd}, \mathrm{Cu}, \mathrm{Pb}$ and $\mathrm{Zn}$ with sequentialextraction in contaminated and non-contaminated soils. Int. J. Environ. Sci. Tech. 2007. 4 (2): 169-176,. 